\title{
Pelatihan Membuat Soal Tes Hasil Belajar Berbasis High Order Thinking Skill untuk Guru SMA-SMP Sederajat di Kabupaten Rokan Hilir Provinsi Riau
}

\author{
Asyrul Fikri, Ahmal, Yanuar Al Fiqri*, Nurdiansyah \\ Program Studi Pendidikan Sejarah FKIP Universitas Riau \\ *Corresponding Author. Email: yanuar.al@ lecturer.unri.ac.id
}

\begin{abstract}
The purpose of this activity is to give an ability for the Teacher of Middle and High Schools in Kecamatan Tanah Putih, Riau Province to understand and be able to apply the HOTS evaluation method at their respective schools and students. The methods used are lectures, questions and answers, trials/simulations, and workshop. The results of this training activity that has been carried out, it can be concluded that the objectives of the activity have been successfully achieved. This is evidenced by the excellent enthusiasm of the trainees during the discussion process and the results of the assignments given to the presenters to the trainees, indicating an increase in the understanding and ability of teachers to integrate HOTS into learning outcomes test instrument.
\end{abstract}

\begin{abstract}
Abstrak: Tujuan kegiatan pengabdian ini adalah untuk meningkatkan pemahaman dan Kompetensi Guru-guru SMP dan SMA Sederajat seKecamatan Tanah Putih Kabupaten Rokan Hilir Provinsi Riau melalui pelatihan membuat soal tes hasil belajar berbasis HOTS. Metode yang digunakan adalah ceramah, tanya jawab, uji coba/simulasi dan workshop. Dari hasil kegiatan pelatihan yang telah terlaksana dapat disimpulkan bahwa tujuan kegiatan berhasil tercapai dengan baik. Ini dibuktikan dengan antusiasme peserta pelatihan yang sangat baik pada saat proses diskusi dan hasil tugas yang diberikan kepada pemateri kepada peserta pelatihan, menunjukkan adanya peningkatan pemahaman serta kemampuan guru dlam mengintegrasikan HOTS kedalam soal-soal hasil belajar.
\end{abstract}

How to Cite: Fikri, A., Ahmal, A., Al Fiqri, Y., \& Nurdiansyah, N. (2021). Pelatihan Membuat Soal Tes Hasil Belajar Berbasis High Order Thinking Skill untuk Guru SMA-SMP Sederajat di Kabupaten Rokan Hilir Provinsi Riau. Jurnal Pengabdian UNDIKMA, 2(2), 150-156. doi:https://doi.org/10.33394/jpu.v2i2.4156

https://doi.org/10.33394/jpu.v2i2.4156

\author{
Article History: \\ Received: 17-09-2021 \\ Reviewed: 01-10-2021 \\ Accepted: 21-10-2021 \\ Published: 13-11-2021
}

Key Words:

Training, HOTS,

Evaluation, Teacher.

Sejarah Artikel:

Diterima: 17-09-2021

Direview: 01-10-2021

Disetujui: 21-10-2021

Diterbitkan: 13-11-2021

\section{Kata Kunci:}

Pelatihan, HOTS,

Evaluasi, Guru.

\section{Pendahuluan}

Guru merupakan garda terdepan sebuah Negara dalam memajukan bangsanya. Kualitas pendidikan dan pengajaran yang diberikan oleg guru kepada generasi penerus, menjadi modal utama dalam perkembangan dan kemajuan Negara itu. Sebagai garda terdepan, maka kemampuan yang dimiliki para guru ini harus mumpuni. Karena keberhasilan seorang peserta didik dalam pendidikan, tidak lepas dari kualitas guru yang mengajar mereka pula. Jika para guru belum memiliki skill dan keterampilan serta ilmu yang baik, maka bisa dipastikan kualitas anak didik yang dihasilkan akan buruk. Maka dari itu sangat penting bagi para guru untuk menguasai berbagai ilmu dan metode-metode pengajaran, pembelajaran dan penilaian yang tinggi dan selalu up to date dalam perkembangan zaman.

Tugas guru disekolah tidak hanya memperikan materi ajar, namun bertanggung jawab juga dalam menilai hasil belajar para peserta didiknya. Penilaian ini sangat berguna untuk mengetahui sejauh mana taraf penguasaan siswa terhadap materi ajar, keberhasilan guru dalam memberikan materi serta kualitas dari kurikulum yang diterapkan oleh lembaga 
pendidikan Negara tersebut. Kebanyakan guru lebih terfokus kepada pengembangan skill mengajar mereka, dalam hal ini mereka mempelajari berbagai model dan metode pembelajaran yang akan membantu guru dalam maengajar dan juga membantu siswa dalam memahami materi ajar yang disampaikan oleh guru. Tetapi para guru belum terlihat mencoba mengeksplorasi berbagai model dan bentuk penilaian hasil belajar yang mutakhir.

Salah satu model penilaian hasil belajar terbaru tersebut adalah penggunaan soal-soal tes hasil belajar yang berbasis High Order Thinking Skill atau kemampuan berpikir tingkat tinggi. Bentuk-bentuk soalh hasil belajar model ini, disusun dan dibuat sedemikian rupa untuk tidak hanya mengukur dan mengevaluasi hsil belajar siswa semata, namun bisa digunakan untuk mengevaluasi seberapa besar kemampuan siswa dalam berfikir tingkat tinggi (HOTS). Hots sendiri secara sederhana dapat diartikan sebagai kemampuan berpikir yang tidak lagi terfokus kepada level-level rendah. Pada kemapuan berpikir kognitif, Anderson (2015) membaginya menjadi enam tingkatan level berfikir, yaitu, Mengingat (C1), Memahami (C2), Mengaplikasikan (C3), Menganalisi (C4), Mengevaluasi (C5) dan Mencipta (C6). Level kognitif $\mathrm{C} 1$ sampai $\mathrm{C} 3$ ini disebut dengan level berpikir tingkat rendah dan $\mathrm{C} 4$ sampai C6 yang disebut dengan level berpikir tingkat tinggi. Maka dari itu soal-soal tes hasil belajar yang dibuat oleh guru untuk menilai dan mengevaluasi siswa, akan sangat baik jika didominasi oleh soal-soal level tinggi ini.

Higher Order Thinking Skill (HOTS) atau kemampuan berpikir tingkat tinggi adalah proses berpikir yang mengharuskan siswa untuk memanipulasi informasi yang ada dan ideide dengan cara tertentu yang memberikan mereka pengertian dan implikasi baru. Misalnya, ketika siswa menggabungkan fakta dan ide dalam proses mensintesis, melakukan generalisasi, menjelaskan, melakukan hipotesis dan analisis, hingga siswa sampai pada suatu kesimpulan. Sedangkan menurut Brookhart dalam Hidayati (2017) keterampilan berpikir tingkat tinggi dikategorikan kedalam 3 bagian yaitu: (1) " ... define higher order thinking in terms of transfer". (2) "... define it in terms of critical thinking". Dan (3) "... define it in terms of problem solving". Dalam hal ini definisi keterampilan berpikir tingkat tinggi dikategorikan kedalam 3 bagian yaitu (1) sebagai bentuk hasil transfer hasil belajar, (2) sebagai bentuk berpikir kritis, dan (3) sebagai proses pemecahan masalah. Tujuan utama dari high order thinking skills adalah bagaimana meningkatkan kemampuan berpikir peserta didik pada level yang lebih tinggi, terutama yang berkaitan dengan kemampuan untuk berpikir secara kritis dalam menerima berbagai jenis informasi, berpikir kreatif dalam memecahkan suatu masalah menggunakan pengetahuan yang dimiliki serta membuat keputusan dalam situasi-situasi yang kompleks (Saputra, 2016).

Mengimplementasikan keterampilan berpikir tingkat tinggi dalam kelas bukanlah hal yang mudah, tentunya harus ada usaha yang maksimal dalam mewujudkannya. Guru dalam kelas memiliki peran penting dalam mengatur dan memotivasi siswa untuk berpikir tingkat tinggi, berikut ini beberapa motivasi yang dapat dilakukan guru di kelas menurut Conklin \& Manfro (2010):

a) Membuka pelajaran dengan pertanyaan-pertanyaan yang mengarah pada HOTS untuk mengawali diskusi dan debat.

b) Mengakhiri pelajaran dengan pertanyaan-pertanyaan HOTS yang digunakan sebagai alat penilaian.

c) Menempatkan aktivitas brainstorming pada pertengahan pelajaran untuk mendorong siswa menemukan ide dan berpikir kreatif.

d) Memberikan tugas berbasis open ended sebagai pekerjaan rumah untuk mengetahui kreativitas dan pemahaman mereka terhadap pelajaran yang sudah dipelajari. 
Kemampuan berpikir tingkat tinggi termasuk kemampuan untuk memecahkan masalah (problem solving), keterampilan berpikir kritis (critical thinking), berpikir kreatif (creative thinking), kemampuan berargumen (reasoning), dan kemampuan mengambil keputusan (decision making). Kemampuan berpikir tingkat tinggi merupakan salah satu kompetensi penting dalam dunia modern, sehingga wajib dimiliki oleh setiap peserta didik (Widanal, 2017). Widodo dan Kadarwati (2013) juga menyatakan bahwa dengan berpikir tingkat tinggi, peserta didik menjadi pemikir yang mandiri, argumen yang dikemukakan siswa dapat merupakan petunjuk kualitas kemampuan siswa. Dengan menerapkan berpikir tingkat tinggi sebagai salah satu pendekatan pembelajaran dapat menghasilkan aktivitas belajar yang produktif khususnya dalam interaksi socio-cognitive, misalnya dalam hal: (1) memberi dan menerima bantuan; (2) mengubah dan melengkapi sumber informasi; (3) mengelaborasi dan menjelaskan konsep; (4) berbagi pengetahuan dengan teman; (5) saling memberi dan menerima balikan; (6) menyelesaikan tugas dalam bentuk kolaboratif, dan (7) berkontribusi dalam menghadapi tantangan (Widodo dan kadarwati, 2013).

High order thinking skills (HOTS) atau keterampilan berpikir tingkat tinggi juga merupakan bagian dari taksonomi Bloom hasil revisi yang berupa kata kerja operasional yang terdiri dari menganalisis (C4), mengevaluasi (C5) dan mencipta (C6) yang dapat digunakan dalam penyusunan soal (Fanani, 2018). Menurut Dinni, (2018) revisi teksonomi bloom yang dilakukan oleh Anderson dan Krathwohl lebih berfokus pada bagaimana domain kognitif lebih hidup dan aplikatif bagi pendidik dan praktik pembelajaran yang diharapkan dapat membantu pendidik dalam mengolah dan merumuskan tujuan pembelajaran dan strategi penilaian yang efisien. Ketiga konsep di atas yang menjadi dasar high order thinking skills merujuk pada aktivitas menganalisis, mengevaluasi, mencipta pengetahuan yang disesuaikan dengan konseptual, prosedural dan metakognitif. Menurut Krathwohl dalam Dinni (2018) dalam A revision of Bloom's Taxonomy, menyatakan bahwa indikator untuk mengukur kemampuan berpikir tingkat tinggi meliputi menganalisis (C4) yaitu kemampuan memisahkan konsep ke dalam beberapa komponen dan menghubungkan satu sama lain untuk memperoleh pemahaman atas konsep secara utuh, mengevaluasi (C5) yaitu kemampua menetapkan derajat sesuatu berdasarkan norma, kriteria atau patokan tertentu, dan mencipta (C6) yaitu kemampuan memadukan unsur-unsur menjadi sesuatu bentuk baru yang utuh dan luas, atau membuat sesuatu yang orisinil.

Soal-soal HOTS (Higher Order Thinking Skills/HOTS) atau soal-soal yang mengukur kemampuan berpikir tingkat tinggi merupakan instrumen pengukuran yang digunakan untuk mengukur kemampuan berpikir tingkat tinggi, yaitu kemampuan berpikir yang tidak sekadar mengingat (recall), menyatakan kembali (restate), atau merujuk tanpa melakukan pengolahan (recite). Soal-soal HOTS pada konteks asesmen mengukur kemampuan: 1) transfer satu konsep ke konsep lainnya, 2) memproses dan menerapkan informasi, 3) mencari kaitan dari berbagai informasi yang berbeda-beda, 4) menggunakan informasi untuk menyelesaikan masalah, dan 5) menelaah ide dan informasi secara kritis. (Widana:2017)

Penerapan kurikulum 2013 juga mendukung diterapkan nya HOTS dalam penilaian peserta didik disekolah. Penyempurnaan kurikulum 2013 antara lain pada standar isi diperkaya dengan kebutuhan peserta didik untuk berpikir kritis dan analitis sesuai dengan standar internasional, sedangkan pada standar penilaian memberi ruang pada pengembangan instrumen penilaian yang mengukur berpikir tingkat tinggi. Penilaian hasil belajar diharapkan dapat membantu peserta didik untuk meningkatkan kemampuan berpikir tingkat tinggi (Higher Order Thinking Skills/HOTS), karena berpikir tingkat tinggi dapat mendorong peserta didik untuk berpikir secara luas dan mendalam tentang materi pelajaran (Dirjen Guru 
dan Tenaga Kependidikan Kemendikbud, 2018). Berdasarkan penjelasan diatas, maka sangat penting bagi Guru SMP dan SMA di Kecamatan tanah Putih untuk bisa membuat dan menerapkan soal-soal berbasis HOTS dalam evaluasi hasil belajar peserta didik mereka disekolah. Berdasarkan pertimbangan tersebutlah, maka kegiatan pelatihan ini dilaksanakan.

\section{Metode Pengabdian}

Metode yang digunakan pada kegiatan pengabdian ini adalah pelatihan membuat soal tes hasil belajar berbasis HOTS melalui ceramah, tanya jawab, uji coba/simulasi dan terakhir Workshop. Kegiatan dilaksanakan di aula SMPN 05 Tanah Putih, Rokan Hilir. Kegiatan di mulai dengan (1) Menanyakan pengetahuan guru tentang konsep HOTS, (2) Memberikan beberapa contoh definisi HOTS dari para ahli pendidikan, (3) Menyampaikan kepada guru perbedaaan antara soal-soal tes berbasis HOTS dengan soal-soal tes konvensional (4) Mengajarkan kepada guru mengenai penyusunan dan pembuatan soal-soal berbasis HOTS.

\section{Hasil Pengabdian dan Pembahasan}

Rokan Hilir merupakan bekas wilayah kewedanaan Bagan siapiapi yang terdiri dari Kecamatan Tanah Putih, Kubu dan Bangko serta ditambah kecamatan pemekaran yaitu Kecamatan Rimba Melintang dan Kecamatan Bagan Sinembah kemudian pada tanggal 4 Oktober 1999 ditetapkan oleh Pemerintah Republik Indonesia sebagai Kabupaten Baru di Provinsi Riau sesuai dengan Undang-undang Nomor 53 tahun 1999. Selanjutnya dengan Undang-undang Nomor 34 Tahun 2008 ditetapkan Bagansiapiapi sebagai Ibukota Kabupaten Rokan Hilir. Pusat Pemerintahan berada di Komplek Perkantoran Batu Enam Bagansiapiapi yang memiliki panorama yang indah karena berada di tepi muara sungai rokan yang berhadapan langsung ke laut selat melaka. Wilayah Kabupaten Rokan Hilir terletak pada bagian pesisir timur Pulau Sumatera antara 1014'-2030' LU dan 100016'-101021' BT. Luas Wilayah Kabupaten Rokan Hilir adalah 8.881,59 KM2, Kabupaten Rokan Hilir memiliki 18 Kecamatan, Kecamatan terluas adalah Kecamatan Tanah Putih seluas 1.915,23 KM2 dan kecamatan terkecil adalah Kecamatan Tanah Putih Tanjung Melawan dengan luas wilayah 198,39 KM2. Berikut jumlah data satuan pendidikan di kabupaten Rokan Hilir yang diambil dari pusat data Kementerian Pendidikan dan kebudayaan:

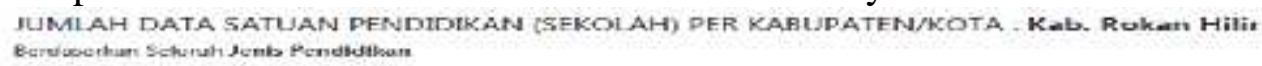

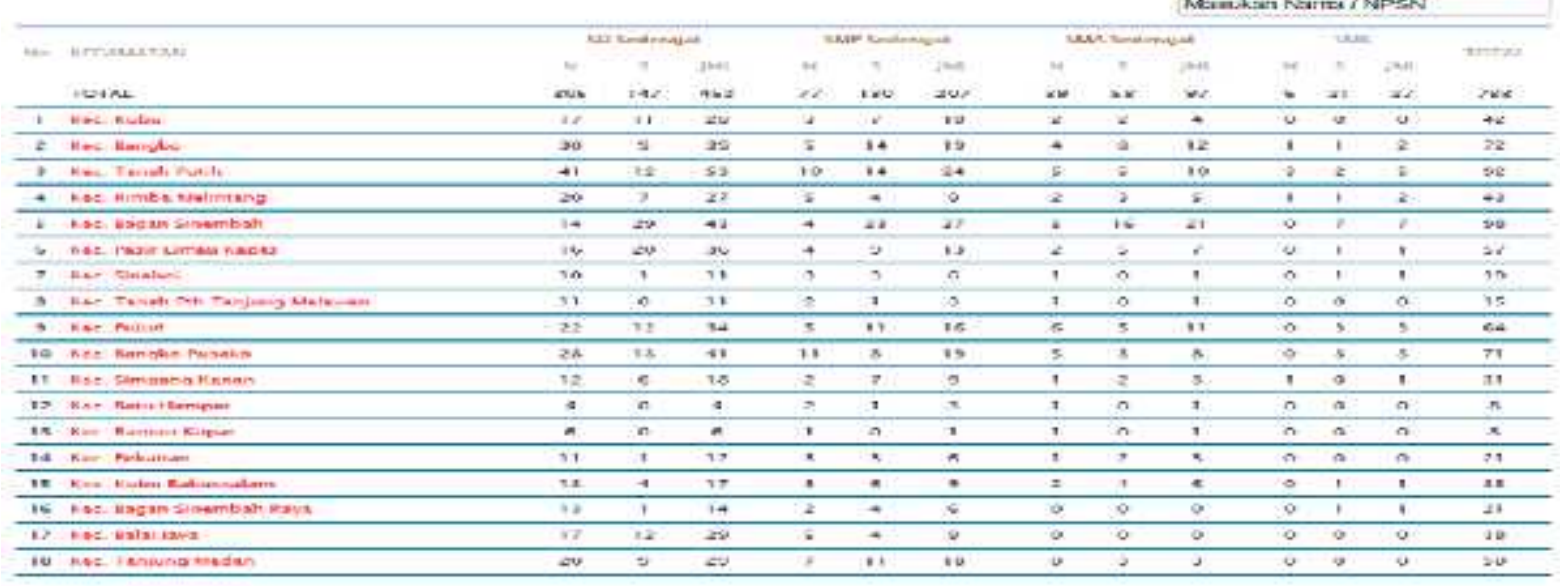

Gambar 1. Data Sekolah di Kabupaten Rokan Hilir Provinsi Riau (https//referensi.data.kemdikbud.go.id) 
Berdasarkan data diatas, tercatat bahwa daerah sasaran yakitu Kecamatan tanah putih memiliki 72 satuan pendidikan.

Dari sekian banyak satuan pendidikan, artinya juga banyak guru di kabupaten Rokan Hiril Riau. Berdasarkan hasil survey, masih diperlukan adanya pelatihan Membuat Soal Tes Hasil Belajar Berbasis High Order Thinking Skill yang diadakan di kabupaten Rokan Hilir, khususnya Kecamatan Tanah putih. Hal ini akan sangat berguna bagi guru dalam membantu proses penanaman critical thinking dan problem solving untuk siswa-siswa di Kecamatan tanah putih. Terlebih lagi berdasarkan data kemendikbud, sebagian besar wilayah tanah Putih masih masuk dalam kategori daerah tertinggal dan sangat tertinggal.

I)A.I I A.R I) LA/KII ULAAIIAN.

Kec. Tanah Putlh

\begin{tabular}{|c|c|c|}
\hline Na: & NALS חFSA KFIIIIAHAN & SATIS VMAYAH \\
\hline 1 & Fonbar al & \\
\hline 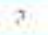 & MFICSIAL 2 SAKTI & - reringoni \\
\hline 3 & MER:CCAL: 5EAPLRKA & Telinivgd. \\
\hline 4 & Mumuqo & ertincas: \\
\hline q & That & 5 nngat $->n$ nansl \\
\hline$f$ & Panto fals & - rerringyai \\
\hline 7 & $5=\operatorname{Jin} u \tan$ & \\
\hline $\mathrm{t}$ & sexcindi & Jangat sit naqa \\
\hline$?$ & SFXFIADI HAIIU & 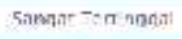 \\
\hline 10 & $\operatorname{sintr} 19$ & -meringat: \\
\hline 11 & इ МTONC ENKTI & Teitinval \\
\hline 12 & S VIUL Maksuk & ertinegai \\
\hline $1=$ & 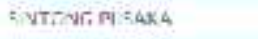 & - rrrinnni: \\
\hline 14 & Triak Firrminur & Sangat - \\
\hline $1 \%$ & Teluk Melas & Tetitivgal \\
\hline is: & juำ $\mathrm{t}$ =iura: & Vercemband \\
\hline
\end{tabular}

Gambar 2. Daftar kategori Desa tertinggal di Kecamatan Tanah Putih Provinsi Riau (https//referensi.data.kemdikbud.go.id)

Tahap persiapan ini meliputi persiapan administrasi dan persiapan teknis kegiatan pengabdian kepada masyarakat. Persiapan administrasi dilakukan berupa persiapan surat menyurat yang berkaitan dengan kegiatan pengabdian di lapangan. Hal itu dilakukan menandakan bahwa kegiatan ini bersifat resmi dan diketahui oleh institusi, dalam hal ini diketahui oleh FKIP Universitas Riau. Apabila kegiatan ini dilakukan maka dapat dipahami legalitasnya oleh lembaga yang diajak bekerjasama atau yang bersedia mendukung terselenggaranya kegiatan pengabdian kepada masyarakat ini. Selanjutnya, persiapan teknis yaitu persiapan berkaitan dengan teknis kegiatan pengabdian ini. Dimulai dari kegiatan sebelum ke lapangan hingga terselenggaranya kegiatan pelatihan di lapangan. Dalam proses persiapan ini, kami tim pengabdian telah melakukan rapat berkali-kali hingga terselenggaranya kegiatan pengabdian ini, apakah kegiatan ini benar-benar bisa dilaksanakan secara langsung dengan protocol kesehatan. Berdasarkan berkoordinasi dengan instansi terkait ternyata memungkinkan dan sekolah mendukung penuh pelaksanaan kegiatan ini.

Kegiatan ini dilaksanakan dengan format Pelatihan langsung di lapangan, yakni para peserta pengabdian diwajibkan mengikuti protocol kesehatan sebelum memasuki ruangan kegiatan. Format pelatihan langsung ini dilaksanakan agar dapat praktik langsung dan ketercapaian pengabdian dapat dilaksanakan secara lebih maksimal. Tentu pelaksanaaan 
kegiatan pelatihan langsung yang diadakan di SMP 05 Tanah Putih ini dilaksanakan dengan standard COVID-19, yakni memakai masker, mengatur jarak, dan pemberian handsanitaizer oleh tim pengabdian. Pada saat kegiatan lapangan para narasumber dilakukan oleh semua tim pengabdian yakni para dosen (tim pengabdian) yang berasal dari Prodi Pendidikan Sejarah FKIP Universitas Riau, dengan uraian materi sebagai berikut:

1) Pembahasan tentang Konsep HOTS disampaikan oleh Dra. Bedriati Ibrahim, M.Si

2) Pembahasan Tentang Pentingnya HOTS dalam Pembelajaran Sejarah disampaikan oleh Dr. Ahmal, M.Hum.

3) Materi penyusunan Soal Tes Hasil Belajar Berbasis HOTS, disampaikan oleh Yanuar Al Fiqri, M.Pd

4) Kegiatan selanjutnya adalah diskusi dan Tanya jawab.

5) Dilanjutkan dengan praktek penyusunan Soal HOTS yang dilaksanakan oleh peserta pengabdian dalam bentuk daring.
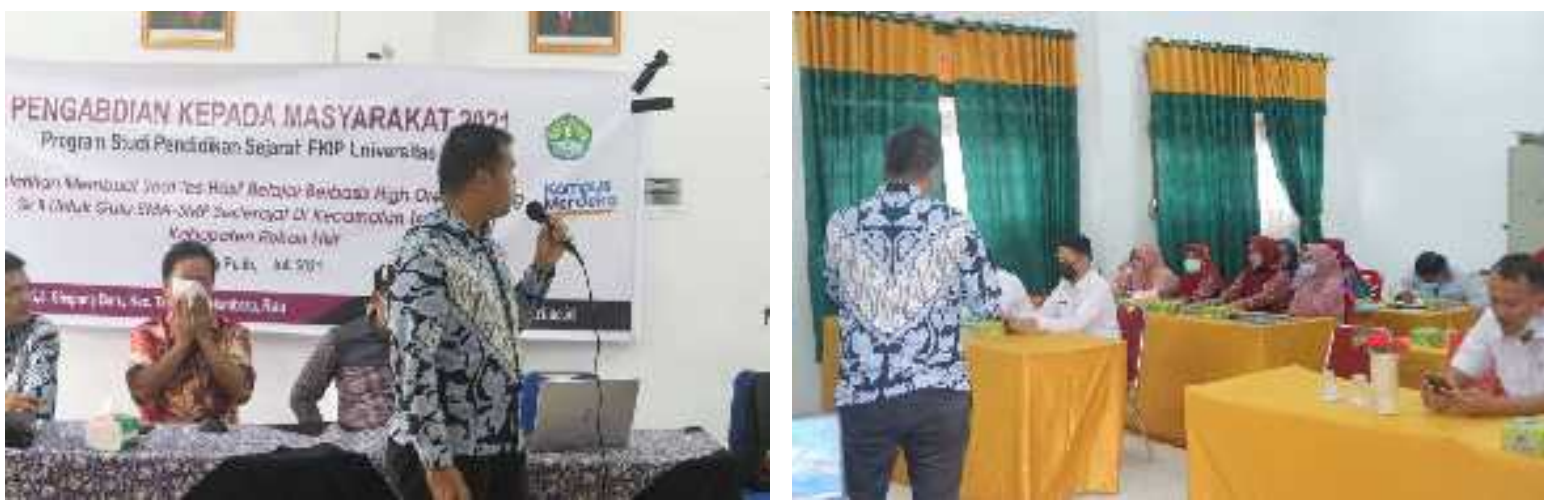

Gambar 3. Dokumentasi Kegiatan pengabdian

Hasli pengabdian ini dapat telihat pada proses diskusi serta hasil penugasan yang telah dikerjakan oleh Guru-guru peserta kegiatan pelatihan. Pada saat diskusi, antusiasme peserta terlihat sangat tinggi, ini dapat terlihat dari banyaknya pertanyaan yang di berikan oleh guru kepada pemateri. Pertanyaan ini meliputi bagaimana penerapan soal HOTS pada mata pelajaran dan materi yang bersifat praktek, bobot penilaian untuk soal-soal berbasis HOTS dan lainnya. Untuk mengehatuhi sejauh mana tingkat pemahaman guru dalam mengaplikasikan HOTS ke soal-soal hasil belajar, maka mereka diberikan tugas untuk membuat soal berbasis HOTS sebanyak 10 butir soal dan disesuaikan dengan mata pelajaran yang diajar. Penugasan ini dilaksanakan secara off site dan guru diberikan waktu selama dua hari setelah kegiatan penyampaian materi dilaksanakan. Hasil penugasan pun memperlihatkan bahwa sekitar $80 \%$ peserta yang mengikuti pelatihan, telah mampu untuk mengintegrasikan HOTS kedalam soal-soal penilaian hasil belajar yang mereka buat, dan kepada guru yang telah berhasil menyelesaikan kegiatan pelatihan dan mengerjakan tugas dengan baik, maka diberikan sertifikat pelatihan, sebagai bukti atas keberhasilan mereka.

\section{Kesimpulan}

Kesimpulan yang diperoleh dari kegiatan pelatihan ini adalah: (1) kegiatan ini dapat mencapai target peserta, yakni hadir sebanyak 30 peserta guru-guru SMA di Kecamatan Tanah Putih Kab. Rokan Hilir, Riau. (1) Tujuan pelatihan yang bisa dinyatakan berhasil. Kemampuan peserta dalam penguasaan materi yang awalnya peserta banyak tidak memahami tentang HOTS, bahkan ada beberapa yang sama sekali baru mendengan tentang HOTS, setelah mengikuti pelatihan ini, para guru telah mampu untuk mengintegrasikan HOTS dalam 
proses pembelajaran dan mengevaluasi Hasil belajar siswa mereka masing-masing. Keberhasilan ini dibuktikan dengan hasil tugas-tugas yang telah dikerjakan oleh peserta pelatihan. Oleh karena itu, ketercapaian target kegiatan pengabdian kepada masyarakat ini dapat tergolong secara baik, karena materi pendampingan telah dapat disampaikan secara keseluruhan dan ditambah praktik.

\section{Saran}

Berdasarkan hasil kegiatan pengabdian, maka dapat diberikan saran kepada seluruh kepala sekolah yang memimpin SMP-SMA sederajat di Kecamatan tanah putih untuk mewajibkan guru-guru mengintegrasikan HOTS kedalam setiap porses penilaian hasil belajar yang dilakukan. Tidak hanya terpaku kepada ulangan harian, namun untuk ujian akhir semester serta ujian kenaikan kelas. Hal ini diperlukan agar kemampuan guru dalam membuat soal HOTS dapat terasah secara lebih baik dan peserta didik disekolah terbiasa untuk menjawab soal yang benar-benar mengasah kemampuan berpikir tingat tinggi mereka. Kepada Fakultas Keguruan dan Ilmu Pendidikan Universitas Riau, diharapkan untuk dapat terus mendukung kegiatan pelatihan HOTS ini sehingga dapat terlaksana di wilayah-wilayah kecamatan lain yang ada di Provinsi Riau.

\section{Daftar Pustaka}

Anderson, Lorin W dan David R. Krathwohl. (2015). Kerangka landasan untuk Pembelajaran, Pengajaran dan Asesmen.Jakarta: Pustaka pelajar

Dinni, Husna Nur. (2018). HOTS (High Order Thinking Skills) dan Kaitannya dengan Kemampuan Literasi Matematika, Prosiding Seminar Pendidikan Matematika.PRISMA1(2018) https://journal.unnes.ac.id/sju/index.php/prismal.

Fanani, Mohammad Zainal.(2018). Strategi Pengembangan Soal Higher Order Thinking Skill (HOTS) Dalam Kurikulum 2013. Edudeena, Journal of Islamic Religious Education. Vol.II, No.1 Januari 2018.

Wahidmurni (2018), Pengembangan Penilaian Untuk Mengukur Kemampuan Berpikir Tingkat Tinggi (Higer Order Thinking Skills/HOTS). Workshop Pengembangan Penilaian Kurikulum 13 Bagi Guru-guru Madrasah Aliyah Negeri Batu. 13 Juli 2018.

Widodo, Tri dan Sri Kadarwati (2013). High Order Thinking Berbasi Pemecahan Masalah Untuk meningkatkan Hasil Belajar Berorientasi Pembentukan Karakter Siswa. Cakrawala Pendidikan, Februari 2013, Th. XXXII, No. 1.

Widana, I Wayan (2017). Modul Penyusunan Soal Higher Order Thinking Skill, Jakarta: Direktorat Jenderal pendidikan Dasar dan Menengah Kementerian Pendidikan dan Kebudayaan.

W. Conklin \& J. Manfro (2010). Higher order thinking skills to develop 21st century learners. Huntington:Shell Education Publishing Inc.

Wahyuni, Yusri dan Fauziah (2018). Higher Order Thinking Skill Instrumen Design Of Student Based On Bloom's Taxonomy. American Journal of Engineering Research. Vol.7 Issue.8.2018. 